\title{
Evaluation of Aloe vera genotypes against leaf rot disease under field condition
}

\author{
Susheel Kumar ${ }^{1} \cdot$ S. K. Pande ${ }^{1} \cdot$ S. K. Singh ${ }^{1} \cdot$ Jay Kumar Yadav $^{1} \cdot$ Rajesh Saini $^{1}$
}

(c) The Author(s) 2018

\begin{abstract}
Aloe vera (Aloe barbadensis) is a perennial, succulent plant belongs to the family Liliaceae. Aloe vera leaf rot is one of the major limiting factors in Aloe vera production, which decreases leaf, gel quantity and quality significantly. The experiment was conducted to evaluate the genotypes of Aloe vera against leaf rot disease Out of 26 genotypes, none of genotypes was found the free from disease, three genotypes viz, IC-111280, IC-112531 and IC-112513 were highly resistant, four genotypes viz., IC-111279,IC-112518, IC-285626 and IC-283655 were resistant, nine genotypes viz, IC-310618, IC-471886, IC-310904, IC-112569, IC-112519, IC-112532, IC-310611, IC-310617 and IC-310596 were moderately resistant and rest of the genotype were moderately susceptible to highly susceptible against the disease.
\end{abstract}

Keywords Fusarium oxysporum $\cdot$ Genotypes $\cdot$ Leaf rot $\cdot$ Screening

Aloe vera (Aloe barbadensis Miller) is a perennial, drought resisting succulent plant belong to the family Liliaceae which its believed to have originated in African continent specifically in Egypt (Daodu 2000). There are over 250 species of $A$. vera growing around the world however, only $A$. barbadensis, A. ferox and A. arborescence are used as herbal drugs. Aloe vera is grown largely in South America, Central America, Australia and Africa. Aloe vera is cultivated in fairly large area in many in parts of India. A. barbadensis which revealed three types of leaf spots and root rot disease (Sharma and Samota 2007). A stabilized product is incorporated in a wide variety of preparation, including juice, gel, ointments, cream, lotion and shampoos (Daodu 2000). The leaf yield varied from 0.599 to $2.922 \mathrm{~kg}$ per plant per year due to disease in different genotypes (Abhila and Jessyeutty 2010). The gel/juice is consumed directly and used in many preparations therefore it is necessary to raise plant without use of chemicals. Management of leaf rot disease of Aloe vera is mainly achieved through the use of chemicals. Use of fungicides has led to the emergence of several problems like enviremental pollution, residual effect,

Susheel Kumar

sushee18263@gmail.com

1 Department of Plant Pathology, N.D. University of Agricultural and Technology, Kumarganj, Faizabad, Uttar Pradesh 224 229, India killing of benifecial organisms and devlopment of resistant in pathogen. Therefore, cultivation of resistant genotypes of Aloe vera is one of the desirable management options, but their long term stability virtue of true resistance are need for their confirmation under field condition because the role are mineral metabolism and total soluble phenol an imparting resistance/susceptibility against fungus diseases of plant has been also infested (Ashfaq et al. 2014a, b). The leaf rot resistant genotypes under open field condition have been reported by Kumar (2008). However, very limited information is available on the sources of resistance against leaf rot disease in Aloe vera. In view of the importance of Aloe vera in Indian agriculture, some Aloe vera genotypes were evaluated against leaf rot caused by $F$. oxysporum.

The experiment was conducted during Kharif season 2014 and 2015 at experimental farm of Medicinal and Aromatic Plant at N.D. University of Agriculture \& Technology, Kumarganj, Faizabad. Twenty-six Aloe germplasm/cultivars were screened against $F$. oxysporum. The old suckers were transplanted in second week of July at a spacing of $50 \times 40 \mathrm{~cm}$ in augmented design under field condition for evaluation of their resistance against leaf rot of Aloe vera. Three rows of Aloe leaf rot susceptible cultivar IC-471882 (Check) were planted. Recommended package of cultural practices was followed to raise the crop and to promote natural infection. Ten plants in each plot were randomly selected and tagged for visual observations on symptoms appearance 
at $30,45,60,75$ and 90 days after transplanting. The leaf rot disease severity noted on each genotypes was rated following a severity scale from 0 to 5 (Banerjee and Kalloo 1987) [where $0=$ no disease; $1=1 \%$ disease (HR: highly resistant); $2=1-10 \%$ disease(R: resistant); $3=11-25 \%$ disease (MR: moderately resistant); $4=26-50 \%$ disease (S: susceptible) and $5=$ more than $50 \%$ disease (HS: susceptible)]. Percent disease intensity (PDI) was calculated by formula as given below:
$12.11 \%)$ and IC-112521 $(10.54,11.02 \%)$ in comparison to susceptible check IC-112513 $(79.09,81.35 \%)$ at 2014 and 2015 respectively. Kumar et al. (2006) reported the symptom less reaction against leaf rot disease for certain germplasm under artificial screening. Whereas, highest per cent disease incidence was recorded in IC-112513 (79.09, 81.35\%), CI-112531 (78.56, 79.76\%), IC-310618 (77.56, $79.37 \%)$, IC-283655 (79.25, 77.55\%), IC-112513 (73.56, $69.47 \%)$, and IC-111280 (73.56, 69.47\%). The finding

Percent disease intensity $(\mathrm{PDI})=\frac{\text { Sum of total numerical ratings }}{\text { Total no. of leaves examined } \times \text { maximum disease grade }} \times 100$.

Out of 26 genotypes, none, of the genotypes was free from infection against Aloe leaf rot disease (Table 1). The lowest leaf rot incidence was recorded in IC-112512 (2.27, 3.81\%), IC-471882 (2.72, 3.77\%), IC-285629 (10.55, $10.02 \%)$, IC-112532 (10.30, 11.37\%), IC-111279 (10.63, revealed no significant difference between in the year 2014 and 2015 were observed. The Leaf rot and leaf spot symptoms were showed all the germplasm tested in the field. The rotting symptoms was showed by IC-111279, IC-112518, IC-285626, IC-283655, IC-310618, IC-471886, IC-310904,

Table 1 Incidence of Aloe vera leaf rot (Fusarium oxysporum) on Aloe vera cultivars

\begin{tabular}{|c|c|c|c|c|c|c|c|}
\hline \multirow[t]{2}{*}{ Genotypes } & \multicolumn{3}{|l|}{2014} & \multicolumn{3}{|l|}{2015} & \multirow[t]{2}{*}{ Types of symptoms } \\
\hline & $\begin{array}{l}\text { Total no. of } \\
\text { plants }\end{array}$ & $\begin{array}{l}\text { No. of infected } \\
\text { plants }\end{array}$ & $\begin{array}{l}\text { Percent disease } \\
\text { intensity }\end{array}$ & $\begin{array}{l}\text { Total no. of } \\
\text { plants }\end{array}$ & $\begin{array}{l}\text { No. of infected } \\
\text { plants }\end{array}$ & $\begin{array}{l}\text { Percent disease } \\
\text { intensity }\end{array}$ & \\
\hline IC-285629 & 10 & 4 & 10.55 & 10 & 3 & 10.02 & LS,LR \\
\hline IC-310611 & 10 & 6 & 17.10 & 10 & 6 & 15.42 & LS, LR \\
\hline IC-310596 & 10 & 6 & 20.36 & 10 & 6 & 22.85 & LS, LR \\
\hline IC-310904 & 10 & 7 & 29.75 & 10 & 8 & 32.70 & LS, LR \\
\hline IC-310609 & 10 & 8 & 55.65 & 10 & 7 & 53.76 & LS, LR \\
\hline IC-283610 & 10 & 8 & 57.26 & 10 & 9 & 66.23 & LS, LR \\
\hline IC-310618 & 10 & 10 & 77.56 & 10 & 10 & 79.37 & LS, LR \\
\hline IC-112532 & 10 & 2 & 10.30 & 10 & 3 & 11.37 & LS, LR \\
\hline IC-112519 & 10 & 4 & 26.99 & 10 & 5 & 27.14 & LS, LR \\
\hline IC-310517 & 10 & 6 & 37.12 & 10 & 5 & 34.62 & LS, LR \\
\hline IC-112569 & 10 & 8 & 52.32 & 10 & 7 & 53.18 & LS, LR \\
\hline IC-471886 & 10 & 8 & 56.85 & 10 & 9 & 58.10 & LS, LR \\
\hline IC-112513 & 10 & 10 & 79.09 & 10 & 10 & 81.35 & LS, LR \\
\hline IC-112527 & 10 & 10 & 77.03 & 10 & 10 & 76.55 & LS, LR \\
\hline IC-112531 & 10 & 10 & 78.56 & 10 & 10 & 79.76 & LS, LR \\
\hline IC-310617 & 10 & 10 & 71.51 & 10 & 10 & 70.63 & LS, LR \\
\hline IC-112521 & 10 & 2 & 10.54 & 10 & 2 & 11.01 & LS, LR \\
\hline IC-283945 & 10 & 4 & 21.25 & 10 & 3 & 18.53 & LS, LR \\
\hline IC-285626 & 10 & 10 & 62.34 & 10 & 10 & 60.74 & LS, LR \\
\hline IC-283655 & 10 & 10 & 79.25 & 10 & 7 & 77.55 & LS, LR \\
\hline IC-283943 & 10 & 6 & 51.57 & 10 & 5 & 54.06 & LS, LR \\
\hline IC-111279 & 10 & 47 & 10.63 & 10 & 3 & 12.11 & LS, LR \\
\hline IC-112512 & 10 & 2 & 2.27 & 10 & 3 & 3.81 & LS, LR \\
\hline IC-471882 & 10 & 2 & 2.72 & 10 & 2 & 3.77 & LS, LR \\
\hline IC-112518 & 10 & 4 & 28.73 & 10 & 4 & 26.74 & LS, LR \\
\hline IC-111280 & 10 & 10 & 73.56 & 10 & 10 & 69.47 & LS, LR \\
\hline
\end{tabular}

$\mathrm{LR}=$ leaf rot, $\mathrm{LS}=$ leaf spot 
Table 2 Reaction of Aloe germplasm against leaf rot fungus (Fusarium oxysporum) under field conditions during 2014-2015

\begin{tabular}{|c|c|c|c|}
\hline S. no. & Germplasm & PDI & Reaction \\
\hline 1 & IC-111280 & 0.56 & HR \\
\hline 2 & IC-112531 & 0.77 & HR \\
\hline 3 & IC-112513 & 0.78 & HR \\
\hline 4 & IC-111279 & 3.56 & $\mathrm{R}$ \\
\hline 5 & IC-112518 & 4.23 & $\mathrm{R}$ \\
\hline 6 & IC-285626 & 7.95 & $\mathrm{R}$ \\
\hline 7 & IC-283655 & 8.56 & $\mathrm{R}$ \\
\hline 8 & IC-310618 & 13.65 & MR \\
\hline 9 & IC-471886 & 14.21 & MR \\
\hline 10 & IC-310904 & 15.24 & MR \\
\hline 11 & IC-112569 & 19.23 & MR \\
\hline 12 & IC-112519 & 20.57 & MR \\
\hline 13 & IC-112532 & 22.56 & MR \\
\hline 14 & IC-310611 & 23.21 & MR \\
\hline 15 & IC-310617 & 24.24 & MR \\
\hline 16 & IC-310596 & 24.54 & MR \\
\hline 17 & IC-283610 & 29.56 & S \\
\hline 18 & IC-283945 & 34.23 & S \\
\hline 19 & IC-112512 & 37.46 & S \\
\hline 20 & IC-112527 & 39.43 & $\mathrm{~S}$ \\
\hline 21 & IC-283943 & 40.56 & $\mathrm{~S}$ \\
\hline 22 & IC-310517 & 44.53 & $\mathrm{~S}$ \\
\hline 23 & IC-310609 & 52.74 & HS \\
\hline 24 & IC-112521 & 57.29 & HS \\
\hline 25 & IC-285629 & 66.56 & HS \\
\hline 26 & IC-471882 (check) & 79.23 & HS \\
\hline
\end{tabular}

$H R$ highly resistant, $R$ resistant, $M R$ moderately resistant, $S$ susceptible, $H S$ highly susceptible

IC-112569, IC-112519, IC-112532, IC-310611, IC-310617, IC-310596, IC-283610, IC-283945, IC-112512, IC-112527, IC-283943 and IC-310517 were showed rotting symptoms. These types of symptoms were observed brown to blackish and deep pit symptoms (Table 1).
Field screening of 26 germplasms revealed that three cultivars namely; IC-111280, IC-112531 and IC-112513 showed highly resistant reaction and four germplasms viz., IC-111279, IC-112518, IC-285626 and IC-283655 were resistant to leaf rot, whereas other cultivars showed susceptible to highly susceptible reaction against leaf rot. However, highly resistant and resistant cultivar based on artificial screening has not been done (Table 2). Thus, this study showed the field resistant, artificial screening under challenged condition is necessary in order to develop true resistant cultivars.

Open Access This article is distributed under the terms of the Creative Commons Attribution 4.0 International License (http://creativeco mmons.org/licenses/by/4.0/), which permits unrestricted use, distribution, and reproduction in any medium, provided you give appropriate credit to the original author(s) and the source, provide a link to the Creative Commons license, and indicate if changes were made.

\section{References}

Abhila SR, Jessyeutty (2010) Morphological characterization of Aloe vera germplasm. J Med Arom Plant Sci 33:289-294

Ashfaq M, Iqbal S, Mukhtar T, Shah H (2014a) Screening for resistance to cucumber mosaic cucumovirus in chilli pepper. J Anim Plant Sci 24:791-795

Ashfaq M, Iqbal S, Mukhtar T, Shah H (2014b) Screening for resistance to cucumber mosaic cucumovirus in chilli pepper. J Animal Plant Sci 24(3):791-795

Banerjee MK, Kalloo G (1987) Inheritance of tomato leaf curl virus resistance in Lycopersicon hirsutun f. glabratum. Euphytica 36:581-584

Daodu T (2000) Aloe vera, the miracle healing plant. Health Field Corporation, Lagos, p 36

Kumar S (2008) Screening of germplasm and genetics of resistance against leaf curl virur of Capsicum. Ph.D. thesis, Udai Pratap Autonomous College, Varanasi, India

Kumar S, Kumar S, Singh M, Singh AK, Rai M (2006) Identification of sources and inheritance of Pep. LCV in Capsicum. Sci Hort 110:359-361

Sharma SS, Samota RK (2007) Some new fungal diseases on Aloe barbadensis. Indian Phytopath 60(2):277 